\title{
JAMINAN KEPASTIAN HUKUM PEMBERIAN PERPANJANGAN HAK GUNA USAHA
}

\author{
Mursil \\ Kepala BPN Aceh, Mahasiswa Program Doktor Universitas Jayabaya Jakarta \\ Korespondensi: mursil.m@yahoo.com
}

\begin{abstract}
Abstrak
Kegiatan bisnis sangat menuntut adanya jaminan kepastian hukum. Salah satu persoalan penting terkait dengan kepastian hukum tersebut adalah perpanjangan hak guna usaha. Tulisan ini membahas mengenai jaminan kepastian hukum pemberian perpanjangan hak guna usaha, termasuk perlindungan hukum terhadap investor berkenaan dengan aset yang dimilikinya di atas hak guna usaha ketika permohonan perpanjangan hak guna usahanya tidak dikabulkan. Terkait dengan itu tulisan ini menemukan adanya perbedaan pengaturan antara Peraturan Pemerintah dengan Peraturan Menteri serta tidak memadainya perlindungan hukum kepada investor menyangkut aset-asetnya yang ada di atas hak guna usaha ketika permohonan perpanjangan hak guna usahanya tidak dikabulkan.
\end{abstract}

Kata-kata Kunci: Kepastian Hukum; Hak Guna Usaha; Aset Investor.

\begin{abstract}
Business activities requires guarantees of legal certainty. One of the important issues related to the legal certainty is the extension of the right to cultivate. This paper discusses the legal guarantee provided in the extension of the right to cultivate, including legal protection of the investor in respect of its assets over the right to cultivate when the application for renewal of their right was not granted. This paper revealed that there are differences between the relevant Government Regulation and Minister Regulation as well as inadequacy of legal protection of the investors assets located on the tract of land with the right to cultivate when the application renew that right was not granted.
\end{abstract}

Key Words: Legal Certainty; Right to Cultivate; Investor's Asset. 


\section{PENDAHULUAN}

Pasal 16 ayat (1) Undang-Undang Nomor 5 Tahun 1960 tentang Peraturan Dasar Pokok-Pokok Agraria (selanjutnya disebut UUPA) mengatur tentang macam-macam hak atas tanah, salah satunya adalah Hak Guna Usaha (HGU). HGU ini lebih lanjut diatur pada Pasal 28 sampai dengan Pasal 34 UUPA. Pasal 28 ayat (1) UUPA menyebutkan hak guna usaha adalah hak untuk mengusahakan tanah yang dikuasai langsung oleh negara, dalam jangka waktu sebagaimana tersebut dalam Pasal 29 UUPA, guna perusahaan pertanian, perikanan atau peternakan. Selanjutnya pada Pasal 28 ayat (2) UUPA disebutkan pula hak guna usaha diberikan atas tanah yang luasnya paling sedikit 5 hektar, dengan ketentuan bahwa jika luasnya 25 hektar atau lebih harus memakai investasi modal yang layak dan teknik perusahaan yang baik, sesuai dengan perkembangan zaman. ${ }^{1}$

Dalam prapenelitian di lapangan ditemukan bahwa pada awalnya pemberian HGU dalam skala yang sangat luas tersebut tidak menimbulkan permasalahan, malahan berdampak positif kepada masyarakat di sekitar karena memberi peluang pekerjaan, sehingga mengurangi pengangguran. Hal ini didukung pula oleh UndangUndang Nomor 40 Tahun 2007 tentang Perseroan Terbatas (UU No. 40 Tahun 2007), di mana pada Pasal 74 ayat (1)- nya ditentukan: "Perseroan yang menjalankan kegiatan usahanya di bidang sumber daya alam wajib melaksanakan tanggung jawab sosial dan lingkungan." ${ }^{2}$

Namun, seiring dengan meningkatnya pertambahan jumlah penduduk maka semakin meningkat pula kebutuhan pembangunan infrastruktur, fasilitas umum dan fasilitas sosial. Hal ini mendorong meningkatnya kebutuhan atas tanah sehingga mengakibatkan keberadaan pemukiman penduduk yang semula berjauhan dengan lokasi HGU semakin lama semakin mendekat ke areal HGU bahkan ada lokasi dapur rumah penduduk yang sudah masuk ke dalam lokasi HGU.

Fenomena tersebut telah menimbulkan ketidakpastian hukum bagi para pemegang HGU yang telah menanamkan investasi yang sangat besar bagi pembangunan usaha perkebunan ketika di awal mereka memperoleh hak tersebut bahkan sebelum hak tersebut mereka perolehpun para investor telah mengeluarkan investasi yang besar untuk membangun infrastruktur seperti jalan dan jembatan di lingkungan perkebunan. Sehubungan dengan itu jika HGU yang akan berakhir jangka waktu masa berlakunya maka pemegang haknya akan segera mengajukan permohonan perpanjangan HGUnya. Masalah perpanjangan atau

Supriadi, Hukum Agraria (Sinar Grafika 2008)350.

Habib Adjie, Status Badan Hukum, Prinsip-Prinsip dan Tanggung Jawab Sosial Perseroan Terbatas (CV. Mandar Maju 2008)71. 
pembaharuan HGU ini diatur dalam Pasal 10 ayat (1) Peraturan Pemerintah Nomor 40 Tahun 1996 tentang Hak Guna Usaha, Hak Guna Bangunan dan Hak Pakai atas Tanah (PP No. 40 Tahun 1996) yang menentukan bahwa permohonan perpanjangan jangka waktu HGU atau pembaharuannya diajukan selambat-lambatnya dua tahun sebelum berakhirnya jangka waktu HGU tersebut.

Berdasarkan penelitian lapangan yang penulis lakukan pada Kantor Wilayah Badan Pertanahan Nasional Provinsi Aceh ditemukan ada beberapa kondisi yang menyebabkan jaminan kepastian hukum pemberian perpanjangan dan/atau pembaharuan HGU tersebut mengalami hambatan antara lain:

a. Badan Pertanahan Nasional Republik Indonesia tidak memproses pemberian perpanjangan HGU yang jangka waktu berakhirnya masih di atas dua tahun lagi.

b. Pada umumnya pemegang HGU tidak menguasai seluruh areal yang tercantum dalam isi Surat Ukur/ Peta Bidang Tanah sehingga harus dilakukan pengukuran ulang.

c. Pada saat dilakukan pengukuran ulang terjadi hambatan-hambatan dari masyarakat sekitar, di mana mereka menolak perpanjangan HGU tersebut. d. Tanda-tanda batas/patok lama sudah tidak ditemukan lagi.

e. Proses perpanjangan jangka waktu memerlukan waktu yang lama, sehingga sisa jangka waktu menjadi terlampaui yang mengakibatkan ketika surat Keputusan diterbitkan hak tersebut telah berakhir. ${ }^{3}$

Oleh karena itu, berdasarkan temuan faktual di atas, kepastian hukum dalam perpanjangan HGU merupakan masalah sangat serius. Atas dasar itu maka permasalahan yang ingin penulis bahas di sini adalah kepastian hukum dan perlindungan terhadap hak investor atas aset-aset dan investasi di atas HGU jika ternyata permohonan perpanjangan jangka waktu HGU tersebut tidak dapat dilanjutkan.

\section{PEMBAHASAN}

\section{Aspek-aspek Yuridis tentang Hak Guna Usaha (HGU)}

HGU merupakan hak-hak baru guna memenuhi kebutuhan masyarakat modern dan hanya diberikan terhadap tanah-tanah yang dikuasai langsung oleh negara, jadi tidak terhadap tanah selain milik negara dan tidak terjadi atas suatu perjanjian antara pemilik suatu Hak Milik dengan orang lain. ${ }^{4}$ Berdasarkan Pasal 28 dan 29 UUPA jo. Pasal 8 PP No. 40 Tahun 1996, pengertian HGU adalah hak untuk mengusahakan tanah yang dikuasai langsung oleh negara, dalam jangka

\footnotetext{
3 Hasil wawancara dengan Sarimah, Staf Seksi Pemberian Hak Tanah Badan Hukum, Kantor Wilayah Badan Pertanahan Nasional Provinsi Aceh, tanggal 31 Oktober 2011.

4 A.P. Parlindungan, Komentar Undang-Undang Pokok Agraria (CV. Mandar Maju 1998) 160.
} 
waktu paling lama 25 atau 35 tahun, yang bila diperlukan masih dapat diperpanjang lagi 25 tahun, guna usaha pertanian, perkebunan, perikanan atau peternakan, dengan luas paling sedikit $5 \mathrm{Ha}$.

HGU yang merupakan salah satu hak atas tanah dengan masa berlakunya terbatas untuk jangka waktu tertentu memerlukan kejelasan, baik mengenai persyaratan perolehannya, tata cara pemberian, perpanjangan jangka waktu dan pembaharuan haknya, serta status tanah dan benda-benda yang ada diatasnya sesudah habis jangka waktunya. Semua ini diatur lebih lanjut dalam Peraturan Menteri Negara Agraria/Kepala Badan Pertanahan Nasional Nomor 9 Tahun 1999 tentang Tata Cara Pemberian dan Pembatalan Hak Atas Tanah Negara dan Hak Pengelolaan (Permenag/Ka.BPN No. 9 Tahun 1999).

Subjek HGU sesuai Pasal 30 ayat (1) UUPA jo. Pasal 2 PP No. 40 Tahun 1996 adalah: ${ }^{4}$

\section{a. Warga negara Indonesia}

Sebagai subjek hukum, warga negara Indonesia memiliki otoritas untuk melakukan kewajiban dan mendapatkan haknya. Dengan kata lain, warga negara Indonesia memiliki kewenangan untuk melakukan suatu perbuatan hukum tertentu, misalnya meng-adakan suatu perjanjian, mengadakan perkawinan, mem-buat surat wasiat, dan lain sebagainya termasuk mengadakan suatu perbuatan hukum yang menyangkut dengan tanah dan hak-hak atas tanah. ${ }^{5}$

b. Badan Hukum Indonesia

Untuk dapat menjadi subjek Hak Guna Usaha, badan hukum harus memenuhi syarat-syarat tertentu, yaitu: didirikan menurut ketentuan hukum Indonesia dan berkedudukan di indonesia. Hal ini membawa konsekuensi bahwa setiap badan hukum, selama didirikan menurut ketentuan hukum dan berkedudukan di Indonesia dapat menjadi subjek HGU. Apabila tidak lagi memenuhi syarat di atas maka sesuai Pasal 3 PP No. 40 Tahun 1996, HGU tersebut wajib dilepaskan atau dialihkan kepada pihak lain yang memenuhi syarat dalam jangka waktu satu tahun. Apabila tidak dialihkan, HGU tersebut hapus karena hukum dan tanahnya menjadi tanah negara.

Objek tanah yang dapat diberikan HGU adalah tanah negara. Jika tanah yang diberikan HGU tersebut merupakan kawasan hutan, maka pemberian HGU baru dapat dilakukan setelah ada pencabutan statusnya sebagai kawasan hutan. Demikian juga bila di atas tanah tersebut terdapat hakhak lain, maka pemberian HGU baru dapat dilakukan apabila pelepasan hak yang sebelumnya telah selesai (Pasal 4 PP No. 40 Tahun 1996).

\footnotetext{
$4 \quad$ Chadidjah Dalimunthe, Politik Hukum Agraria Nasional terhadap Hak-Hak atas Tanah (Yayasan Pencerahan Mandailing 2008) 137.

$5 \quad$ Muchsin, Ikhtisar Ilmu Hukum (Badan Penerbit Iblam 2005) 24.
} 
Tidak semua tanah dapat menjadi objek HGU. Tanah-tanah tersebut adalah: tanah yang sudah merupakan perkampungan rakyat, tanah yang sudah diusahakan oleh rakyat secara menetap, dan tanah yang diperlukan oleh pemerintah. ${ }^{5}$

HGU dapat terjadi dengan penetapan pemerintah dan konversi. ${ }^{6}$ Terjadinya HGU karena penetapan pemerintah diatur oleh Pasal 31 dan 37 UUPA, yakni berasal dari tanah yang dikuasai langsung oleh negara yang diberikan pemerintah sebagai HGU kepada yang memerlukannya atas permohonan yang telah diproses sesuai dengan peraturan yang berlaku. Adapun kewenangan negara atau pemerintah dalam menetapkan pemberian hak atas tanah sebagaimana yang diamanatkan pada Pasal 2 ayat (4) UUPA dalam implementasinya diatur lebih lanjut dalam Peraturan Menteri Negara Agraria/Kepala Badan Pertanahan Nasional Nomor 3 Tahun 1999 tentang Pelimpahan Wewenang Pemberian Hak atas Tanah Negara (Permenag/Ka.BPN No. 3 Tahun 1999) yang merupakan pengganti Peraturan Menteri Dalam Negeri Nomor 6 Tahun 1972 tentang Pelimpahan Kewenangan Pemberian Hak atas Tanah (Permendagri No. 6 Tahun 1972).

Dengan demikian sesudah berlakunya peraturan ini maka satusatunya peraturan mengenai pelimpahan kewenangan dalam pemberian hak atas tanah negara adalah peraturan ini. ${ }^{7}$ Sedangkan mengenai tata cara pemberian dan pembatalan hak atas tanah negara dan hak pengelolaan diatur lebih lanjut dengan Permenag/ Ka.BPN No. 9 Tahun 1999.

Dalam UUPA dinyatakan bahwa HGU dapat hapus atau dihapuskan. Selanjutnya menurut Pasal 17 ayat (1) PP No. 40 Tahun 1996, HGU dapat hapus karena:

a. Jangka waktunya berakhir;

b. Dibatalkan haknya oleh pejabat yang berwenang sebelum jangka waktunya berakhir;

c. Dilepaskan oleh pemegang hak sebelum jangka waktunya berakhir;

d. Dicabut berdasarkan UndangUndang Nomor 20 Tahun 1961 tentang Pencabutan Hak-Hak atas Tanah dan Benda-Benda yang Ada di Atasnya (UU No. 20 Tahun 1961);

e. Diterlantarkan;

f. Tanahnya musnah;

g. Ketentuan dalam pasal 3 ayat (2);

Selanjutnya dalam ayat (2) dinyatakan bahwa hapusnya HGU sebagaimana dimaksud dalam ayat (1) mengakibatkan tanahnya menjadi tanah negara.

Setiap subjek pemegang hak atas tanah mempunyai hak dan kewajiban, termasuk subjek HGU. Hak subjek HGU diatur dalam Pasal 14 PP No. 40 Tahun

Sudharyo Soimin, Status Hak dan Pembebasan Tanah (Sinar Grafika 2001) 24.

K. Wantjik Saleh, Hak Anda Atas Tanah (Ghalia Indonesia 1977) 41.

Boedi Harsono, Hukum Agraria Indonesia Himpunan Peraturan-Peraturan Hukium Tanah : Isi dan Pelaksanaannya (Djambatan 2000) 243. 
1996, yang menyatakan bahwa: pemegang HGU berhak menguasai dan mempergunakan tanah yang diberikan dengan HGU untuk melaksanakan usaha di bidang pertanian, perkebunan, perikanan atau peternakan.

Kewajiban pemegang HGU diatur dalam Pasal 12 ayat (1) PP No. 40 Tahun 1996, yang menyatakan bahwa pemegang HGU berkewajiban untuk:

a. membayar uang pemasukan kepada Negara;

b. melaksanakan usaha pertanian, perkebunan, perikanan dan/atau peternakan sesuai dengan peruntukkan dan persyaratan sebagaimana ditetapkan dalam keputusan pemberian haknya;

c. mengusahakan sendiri tanah HGU dengan baik sesuai dengan kelayakan usaha berdasarkan kriteria yang ditetapkan oleh instansi teknis;

d. membangun dan memelihara prasarana lingkungan dan fasilitas tanah yang ada dalam lingkungan areal HGU;

e. memelihara kesuburan tanah, mencegah kerusakan sumber daya alam dan menjaga kelestarian kemampuan lingkungan hidup sesuai dengan peraturan perundangundangan yang berlaku;

f. menyampaikan laporan ter-tulis setiap kahir tahun mengenai penggunaan $\mathrm{HGU}$;

g. menyerahkan kembali tanah yang diberikan dengan HGU kepada Negara sesudah HGU tersebut hapus; h. menyerahkan sertipikat HGU yang telah hapus kepada Kepala Kantor Pertanahan.

Selain itu, pemegang HGU dilarang menyerahkan pengusahaan tanah HGU kepada pihak lain, kecuali dalam halhal diperbolehkan menurut peraturan perundang-undangan yang berlaku.

Jadi, dari hak dan kewajiban pemegang HGU tersebut atas dapat disimpulkan bahwa:

a. Setiap badan hukum yang memohon HGU haruslah mempunyai kemampuan modal untuk mengusahakan tanahnya sesuai rencana kegiatan usaha yang telah ditetapkannya (sesuai site plan atau proposal);

b. Pemegang hak harus sanggup mengusahakan atau mengerjakan sendiri tanahnya secara aktif;

c. Jika tidak mampu me-ngerjakannya sendiri, dapat bekerjasama dengan pihak lain dengan cara yang tidak bertentangan dengan ketentuan perundang-undangan yang berlaku, yaitu tidak dengan jalan pemerasan, akan tetapi dilakukan dengan cara musyawarah dan mufakat terlebih dahulu.

Konsekuensi yuridis terhadap tidak terpenuhinya kewajiban-kewajiban yang ditetapkan tersebut di atas, yang bersangkutan akan dikenakan sanksi yang telah ditetapkan oleh undangundang. 
Proses dan Tata Cara Permohonan Perpanjangan HGU

Instansi pemerintah yang diberikan kewenangan mengurusi administrasi pertanahan adalah Badan Pertanahan Nasional Republik Indonesia (BPN). Salah satu fungsi BPN adalah pengaturan dan penetapan hak-hak atas tanah. Pelaksanaan fungsi pengaturan dan penetapan hak-hak atas tanah dapat dilaksanakan sendiri oleh Kepala BPN, atau dapat juga dilimpahkan kewenangannya kepada Kepala Kantor Wilayah BPN Provinsi, atau Kepala Kantor Pertanahan Kabupaten/Kota. ${ }^{8}$

Dalam melaksanakan tugas dan kewenangannya, instansi BPN tidak bertindak sendiri, khusus-nya dalam hal kewenangan pengurusan HGU perkebunan. Secara teknis yuridis BPN mempunyai kewenangan pemberian legalitas terhadap penguasaan HGU, tetapi dalam pertimbangannya harus mem-perhatikan kelayakan usaha berdasaran kriteria yang ditetapkan oleh instansi teknis terkait, misalnya untuk per-kebunan dari instansi perkebunan, untuk perikanan/ tambak dari instansi perikanan, kemudian untuk peternakan atau lading penggembalaan dari instansi peternakan. Selain itu harus disesuaikan pula dengan kebutuhan dan rencana tata ruang wilayah yang telah ditetapkan oleh Pemerintah Daerah setempat. Dari hal itu maka diperlukan adanya kegiatan koordinasi yang baik sesuai dengan ketentuan yang berlaku.
Sesuai Permenag/Ka.BPN No. 9 Tahun 1999 jo. Peraturan Kepala Badan Pertanahan Nasional Nomor 1 Tahun 2011, sebelum mengajukan permohonan hak maka pemohon terlebih dahulu harus mengajukan permohonannya secara tertulis kepada Kepala Kantor Pertanahan. Prosedur pemberian HGU tersebut dimulai dengan pengajuan permohonan dari perusahaan yang bersangkutan kepada Kepala BPN melalui Kakanwil (Kepala Kantor Wilayah) BPN Provinsi.

Perpanjangan jangka waktu hak atas tanah ini masuk dalam kategori pendaftaran karena perubahan data yuridis, karena terjadinya perubahan jangka waktu berlakunya hak tersebut yang dicantumkan dalam sertifikat tanah yang bersangkutan, meskipun tidak terjadi perubahan subjek dan objeknya. Menurut Pasal 1 angka 9 Permenag/Ka.BPN No. 9 Tahun 1999, "perpanjangan hak adalah penambahan jangka waktu berlakunya suatu hak atas tanah tanpa mengubah syarat-syarat dalam pemberian hak tersebut, yang permohonannya dapat diajukan sebelum jangka waktu berlakunya hak atas tanah yang bersangkutan berakhir."

\section{Jaminan Kepastian Hukum terhadap Investor yang Melakukan Perpanjangan HGU}

Dalam kaitan dengan usaha memperoleh hak atas tanah maka prinsip kepastian hukum memberikan dasar agar dalam pelaksanaan

$10 \quad$ Urip Santoso, Pendaftaran dan Peralihan Hak Atas Tanah (Kencana 2011) 215. 
perolehan hak atas tanah didasarkan pada peraturan perolehan hak atas tanah yang berlaku. Dalam kaitan dengan prinsip ini Maria S.W. Sumardjono mengemukakan bahwa pengadaan tanah dilakukan menurut tata cara yang diatur oleh peraturan perundang-undangan, sehingga para pihak mengetahui hak dan kewajibannya masing-masing. ${ }^{9}$

Sebagaimana diketahui bahwa peraturan perundang-undangan yang ada sering kali tumpang tindih antara peraturan satu dengan peraturan yang lain sehingga dapat menimbulkan ketidakpastian dalam pelaksanaannya. Hal ini akan berakibat tujuan hukum tidak tercapai. Tujuan hukum adalah untuk menciptakan ketertiban dalam masyarakat.

Sebagaimana dikemukakan oleh Sudikno Mertokusumo bahwa tujuan pokok hukum adalah menciptakan tatanan masyarakat yang tertib, menciptakan ketertiban dan keseimbangan. Dengan tercapainya ketertiban di dalam masyarakat diharapkan kepentingan manusia akan terlindungi. ${ }^{10}$

Selain itu hukum harus dilaksanakan dan ditegakkan. Setiap orang mengharapkan dapat diterapkannya hukum dalam hal terjadi peristiwa konkret. Bagaimana hukumnya itulah yang harus berlaku.
Itulah yang diinginkan oleh kepastian hukum. ${ }^{11}$

Tidak terwujudnya kepastian hukum tersebut didorong oleh beberapa faktor seperti: sejarah kepemilikan tanah; psikologi masyarakat; kelemahan aturan pendaftaran tanah; pelaksana dan pelaksanaan; intervensi UndangUndang di bidang Perpajakan (BPHTB dan Biaya Lain). ${ }^{12}$ Keadaan ini menandakan ketidakpastian hukum bagi tanah masyarakat. Maka harus menjadi perhatian pemerintah agar segera mensosialisasikan apa dan bagaimana pendaftaran tanah serta tujuan dilakukan pendaftaran. Bila dibiarkan akan mendorong tidak yakinnya lagi masyarakat atas bukti hak itu sendiri karena dianggap tidak dapat melindungi hak-hak tanah masyarakat. Apalagi bagi sebagian orang, sertipikat tanah masih dianggap hanya dapat dimanfaatkan untuk tujuan tertentu saja sehingga masyarakat masa bodoh atas pendaftaran tanah di negara ini.

Dengan berpijak pada pola pikir inilah baru dapat terwujud cita-cita kepastian hukum atas tanah di negara ini melalui kegiatan pendaftaran tanah. Artinya, untuk mewujudkan kepastian hukum tersebut tidak hanya dilihat dari satu dimensi hukum itu saja, tetapi harus didasarkan pada sikuensi yuridis, yang terencana dalam kehendak tegas

$9 \quad$ Maria S.W. Sumardjono, Tanah dalam Perspektif Hak Ekonomi, Sosial dan Budaya (Penerbit Kompas 2008) 283.

10 Sudikno Mertokusumo, Mengenal Hukum: Suatu Pengantar (Liberty 1985) 58.

11 Ibid. 134.

12 Mhd. Yamin Lubis dan Abd. Rahim Lubis, Hukum Pendaftaran Tanah (CV. Mandar Maju 2010) 178. 
yang berawal dari political will hingga pengawasannya.

Secara faktual, proses permohonan perpanjangan HGU yang diajukan oleh pemegang hak kurang mendapatkan jaminan kepastian hukum. Hal ini dikarenakan adanya beberapa kendala atapun hambatan, baik itu dari segi penerapan peraturan hukumnya maupun kondisi di lapangan. Di dalam penentuan waktu pengajuan permohonan perpanjangan HGU, masyarakat mengacu pada PP No. 40 Tahun 1996 bahwa perpanjangan dapat diajukan selambat-lambatnya 2 (dua) tahun sebelum berakhirnya hak atas tanah tersebut (berarti sebelum dua tahun dapat diajukan permohonannya), sementara Badan Pertanahan Nasional Repubik Indonesia mengacu pada Permenag/Ka.BPN No. 9 Tahun 1999, yakni dapat diajukan dalam tenggang waktu 2 (dua) tahun sebelum berakhirnya hak (berarti sebelum dua tahun tidak dapat diajukan permohonan-nya), berarti hal ini akan memakan waktu yang sangat lama didalam proses pengajuan permohonan hak tersebut sehingga sisa jangka waktu menjadi terlampaui yang mengakibatkan ketika Surat Keputusan diterbitkan hak tersebut telah berakhir. Selain itu juga ada kendala di lapangan, seperti tanda-tanda batas/patok lama sudah tidak ditemukan lagi dan masyarakat di sekitar areal HGU menolak perpanjangan HGU tersebut.

\section{Hak Investor atas Aset dan Investasi di atas HGU yang Permohonan Perpanjangannya Tidak Disetujui}

Jangka waktu pemberian HGU dan perpanjangannya yang selama ini menjadi polemik sebenarnya telah mendapat payung hukum cukup memadai dalam sistem hukum tanah nasional dengan diaturnya ketentuan tersebut dalam undang-undang. HGU dapat diberikan selama 35 (tiga puluh lima) tahun dan dapat diperpanjang selama 25 (dua puluh lima) tahun (Pasal 29 UUPA). Selanjutnya, PP No. 40 Tahun 1996 juga telah menjamin bahwa pemegang HGU dapat mengajukan permohonan per-panjangan ataupun pembaharuan kembali HGU yang dimilikinya jika terpenuhi syarat-syarat: (1) tanahnya masih diusahakan dengan baik sesuai dengan keadaan, sifat dan tujuan pemberian hak tersebut; (2) syarat-syarat pemberian hak tersebut dipenuhi dengan baik oleh pemegang hak; dan (3) pemegang hak masih memenuhi syarat sebagai pemegang hak.

Jika syarat-syarat tersebut tidak terpenuhi maka pengajuan perpanjangan HGU tersebut dapat ditolak. Akibat hukum terhadap HGU yang ditolak, tidak diperpanjang maupun diperbaharui, menurut Pasal 18 PP No. 40 Tahun 1996 adalah sebagai berikut:

(1) Apabila HGU hapus dan tidak diperpanjang atau diperbaharui, bekas pemegang hak wajib membongkar bangunan-bangunan dan benda-benda yang ada di 
atasnya dan menyerahkan tanah dan tanaman yang ada di atas tanah bekas HGU tersebut kepada negara dalam batas waktu yang ditetapkan oleh Menteri.

(2) Apabila bangunan, tanam-an dan benda-benda sebagaimana dimaksud dalam ayat (1) masih diperlukan untuk melangsungkan atau memulihkan pengusahaan tanahnya, maka kepada bekas pemegang hak diberikan ganti rugi yang bentuk dan jumlahnya diatur lebih lanjut dengan Keputusan Presiden.

(3) Pembongkaran bangunan dan benda-benda sebagaimana dimaksud dalam ayat dilaksanakan atas biaya bekas pemegang HGU.

(4) Jika bekas pemegang HGU lalai dalam memenuhi kewajiban sebagaimana dimaksud dalam ayat (3), maka bangunan dan bendabenda yang ada di atas tanah bekas HGU itu dibongkar oleh Pemerintah atas biaya bekas pemegang hak.

Jadi, dari ketentuan di atas jelas bahwa jika permohonan HGU hapus, tidak diperpanjang ataupun tidak perbaharui, maka segala aset yang dimiliki oleh pemilik hak atas tanah sebelum-nya berupa bangunan dan benda lain yang berada di atasnya, harus dibongkar. Sedangkan tanah berikut tanaman yang berada di atas tanah tersebut harus diserahkan atau menjadi milik negara.

\section{PENUTUP}

Hak-hak investor atas aset-aset dan investasi di atas HGU yang permohonan perpanjangan-nya tidak dapat dilanjutkan berimplikasi bahwa segala aset yang dimiliki oleh pemilik hak atas tanah sebelumnya berupa bangunan dan benda lain yang berada di atasnya harus dibongkar. Jika bekas pemegang HGU tersebut tidak melakukan pembongkaran atas bangunan dan benda lain yang berada diatasnya tersebut, maka pemerintah atas biaya bekas pemegang hak akan maelakukan pembongkaran (Pasal 18 ayat (4) PP No. 40 Tahun 1996). Sedangkan tanah berikut tanaman yang berada di atas tanah tersebut harus diserahkan atau menjadi milik negara.

Terkait dengan itu maka penulis menyarankan beberapa hal sebagai berikut. Pertama, dalam hal perpanjangan jangka waktu HGU, sebaiknya BPN mendasarkan diri pada Pasal 10 PP No. 40 Tahun 1996 di mana permohonan tersebut dapat diajukan selambat-lambatnya 2 (dua) tahun sebelum berakhirnya jangka waktu HGU. Hal ini untuk menghindari agar tidak terjadi pembaharuan hak dan untuk menjamin kepastian hukum terhadap pemegang hak sebelumnya.

Kedua, hak-hak yang dimiliki investor atas aset-aset yang telah diinvestasikan diatas HGU yang tidak dapat dilanjutkan permohonan perpanjangan hak-nya, seharusnya diberikan ganti rugi oleh Pemerintah dan selanjutnya tanah bekas hak tersebut dapat diredistribusikan untuk masyarakat setempat sebagai perwujudan reforma agraria. 


\section{DAFTAR BACAAN}

Adjie, Habib, Status Badan Hukum, Prinsip-Prinsip dan Tanggung Jawab Sosial Perseroan Terbatas (CV. Mandar Maju 2008).

Dalimunthe, Chadidjah, Politik Hukum Agraria Nasional terhadap Hak-Hak atas Tanah (Yayasan Pencerahan Mandailing 2008).

Harsono, Boedi, Hukum Agraria Indonesia Himpunan PeraturanPeraturan Hukium Tanah: Isi dan Pelaksanaannya (Djambatan 2000).

Lubis, Mhd. Yamin dan Abd. Rahim Lubis, Hukum Pendaftaran Tanah (CV. Mandar Maju 2010).

Mertokusumo, Sudikno, Mengenal Hukum: Suatu Pengantar (Liberty 1985).

Muchsin, Ikhtisar Ilmu Hukum (Badan Penerbit Iblam 2005).

Parlindungan, A.P., Komentar UndangUndang Pokok Agraria (CV. Mandar Maju 1998).

Saleh, K. Wantjik, Hak Anda Atas Tanah (Ghalia Indonesia 1977).

Santoso, Urip, Pendaftaran dan Peralihan Hak Atas Tanah (Kencana 2011).

Soimin, Sudharyo, Status Hak dan Pembebasan Tanah (Sinar Grafika 2001).

Sumardjono, Maria S.W., Tanah dalam Perspektif Hak Ekonomi, Sosial dan Budaya (Penerbit Kompas 2008).

Supriadi, Hukum Agraria (Sinar Grafika 2008). 
40 